\title{
Assessment of Coastal Modification and Surf Zone Induced Erosion in Itak Abasi Beach, Eastern Niger Delta, Nigeria
}

\author{
Fidelis A. Abija ${ }^{1,2}$ \\ ${ }^{1}$ Centre for Geomechanics, Energy and Environmental Sustainability, Port Harcourt 511101, Nigeria \\ ${ }^{2}$ Mcfaas Int'l Projects Ltd, Km 20 Airport Road, Port Harcourt 511101, Nigeria
}

Corresponding Author Email: fidelabija@yahoo.co.uk

https://doi.org/10.18280/eesrj.060205

Received: 6 March 2019

Accepted: 10 June 2019

Keywords:
beach, volumetric change, erosion,
accretion, surf scaling index

\begin{abstract}
Research aimed at evaluating coastal vulnerability to erosion and shoreline encroachment due to flooding-ebbing cycles of waves. Daily cross sectional topographic profiles were measured from the backshore to the lower foreshore in five study stations at $1 \mathrm{~km}$ interval and surf zone hydrodynamic parameters were monitored. The beach a modern, high energy, mesotidal and dissipative environment with average slope of $\leq 2^{\circ}$ and a width of $90-180 \mathrm{~m}$ and sediments were characteristically fine to very fine grained, poorly to very well sorted sands. Volumetric change depicts all the morphozones but the lower foreshore was dominated by net accretion, the upper foreshore recording the highest volume $\left(+7.92 \mathrm{~m}^{3} / \mathrm{m}\right)$. The lower foreshore had a sediment volume of $-15.0 \mathrm{~m}^{3} / \mathrm{m}$. Time-averaged beach stability index varies from $140-260$, $40-60,15-30,10-36$, and $4-120$ in stations $1,2,3,4$, and 5 respectively and intensity of mobilization decreased with distance from the estuary. Accretion increased with infiltration during tidal flooding indexing a dry beach and low groundwater table. Oversaturation, high groundwater table and exfiltration accounted for erosion at the lower foreshore. Findings are useful for foreshore protection design and prediction of saltwater migration into groundwater aquifers. Beach development for tourism is recommended.
\end{abstract}

\section{INTRODUCTION}

The coastal zone in the Niger delta is inundated by diurnal tides, surf zone induced waves and longshore current subjecting the environment to erosion. Coastal erosion in the region is a major environmental hazard visible in several coastal communities as retreating coastlines and beach hazards have been identified in terms of the vulnerability of coastal areas to damage with regard to loss of property or infrastructure. Coastal infrastructures such as jetties which were accessible without walkways as at the time of design and construction have to be improvised with walkways or totally inaccessible from the shoreline. The beach which is the immediate coastal environment extending from the surf zone to the backshore of the dune region is a highly dynamic environment implying that the sedimentary geologic characteristics of a modern beach may vary markedly in time and space. Sedimentary processes include wind, waves, tides and currents; and organisms and man may also play major roles in determining sedimentary characteristics of beaches. Coastal sediment transport processes result from external processes mainly in the form of tide and wave-driven currents, wind generated waves and currents, or directly by inducing aeolian sediment transport and dune development. The tidal regime and wave climate may exhibit a large spatial variability and play an important role in explaining the diversity in coastal landforms. Swash run-up and beach groundwater processes control the sediment sorting and transport, erosion or accretion on the beach face.

Sediment aggradation and degradation cycles commonly observed on beaches result from complex factors such as sediment mobilization in the breaker and surf zones, longshore current transport, and availability of sediments [1-2] making a generalization of sedimentary processes in beaches impossible. Grant has linked beach ground water behavior and swash zone sediment transport proposing that a "dry" beach (one with a low water table, which he equated with unsaturated conditions below the beach surface) allows swash to infiltrate [3-4]. The reduction in swash depth due to infiltration reduces swash velocity allowing sediment deposition. Therefore, a dry beach promotes accretion. Conversely, on a "wet" beach (one in which the water table is at or near the beach surface) the swash and backwash retain their depth because infiltration is limited. Backwash flows may be augmented by ground water outflow from the beach. It has been generally adduced that infiltration losses during swash run-up favours sediment accretion above the stillwater line.

Coastal engineering require data on swash run-up for design of coastal infrastructures such as breakwaters and USGS report on SWASH [5-6], a new method of monitoring coastal erosion has stressed the importance of data on the shoreline position which depends on swash zone processes for monitoring coastal change. A major limitation on acquisition of this data is the dynamics of the beach environment and the sedimentary processes. Factors which affect sediment mobilization in the breaker and surf zone, longshore current transport, and availability of sediments equally determine beach aggradation and degradation thus making generalization of sedimentary geologic processes of beaches impossible [1-2, 7].

In spite of detailed documentation of tide and wave-induced variability in the hydrodynamic and morphodynamic 
characteristics of beaches, there is a paucity of data on the studied beach. However, some insight into the latter is contained in the works of Antia, and Antia and Nyong [8-12]. The above studies documented beach cusps and geomorphology and proposed morphodynamic models of beach susceptibility to tar pollution as well as implication of beach dynamics to coastal engineering.

In other locations, Heathershaw et al. [13] studied tidal variations in compaction of beach sediments while Engstrom [14] examined beach foreshore sedimentology and morphology in the Apostle Islands, North Winconsin. Greenwood and Hale [2] focused on depth of activity, sediment flux and morphological changes barred nearshore environment, whereas Chaudri et al. [15] examined the sedimentary of beach sediment of the west coast of India. Wadell [16] evaluated swash groundwater - beach profile interactions while temporal and spatial variability in intertidal sedimentation rates has been investigated by Carling [17].

The beach west of Qua Iboe River estuary, called Itak Abasi Beach, is the study location of the present investigation and types and patterns of sedimentary processes, sediment characteristics and net accretion and or erosion in the study area have been evaluated. Section 1 of the research presents introduction and brief review of the concept, section two and three describe the study location and methodology respectively while the results and discussions are presented in section 4. Section 5 Concludes and makes recommendations for future studies and preservation of the study environment.

\section{STUDY LOCATION}

\subsection{Location and geomorphology}

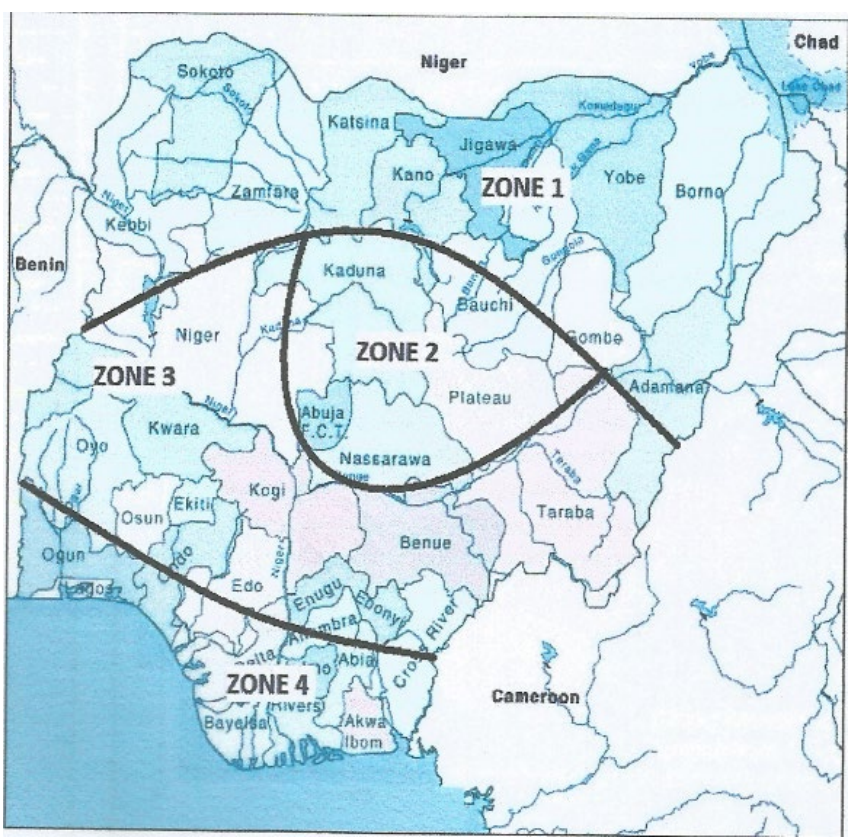

Figure 1. Climatological map of Nigeria showing the study location

Itak Abasi beach is located on the southeastern coast of Nigeria, Eastern Niger Delta (Figure 1). It is part of a modern mesotidal (tidal amplitude 2-4 m) beach stretching between the Qua Iboe River and Imo River estuaries. The studied area is five $\mathrm{km}$ long and is adjacent to the Qua Iboe River estuary. Its geographical coordinates are defined by latitude $7^{\circ} 50^{\prime}$ and $8^{\circ} 00^{\prime}$ North and longitude $4^{\circ} 30^{\prime}$ and $4^{\circ} 33^{\prime}$ East. The physiography of the study area is coastal plain $(<3 \mathrm{~m}$ above mean sea level). It is undeveloped with fine to very fine sand as dominant constituents. Muddy sediments occur occasionally. The beach is wide, extending between 90 and $180 \mathrm{~m}$ from backshore to mean low tide water line. The beach generally shows backshore, berm, and upper, mid and lower four shore zones (Figure 2). However, some segments of the beach lack in berm region. The foreshore slope averages about $2^{\circ}$, although markedly steeper in the vicinity of the estuary. The backshore to upper foreshore transition region generally depicts beach cusps. Some segments of the beach also show scarps ranging between $10-60 \mathrm{~cm}$ in height but typically lack dunes in the backshore (Figures 2 and 3 ).

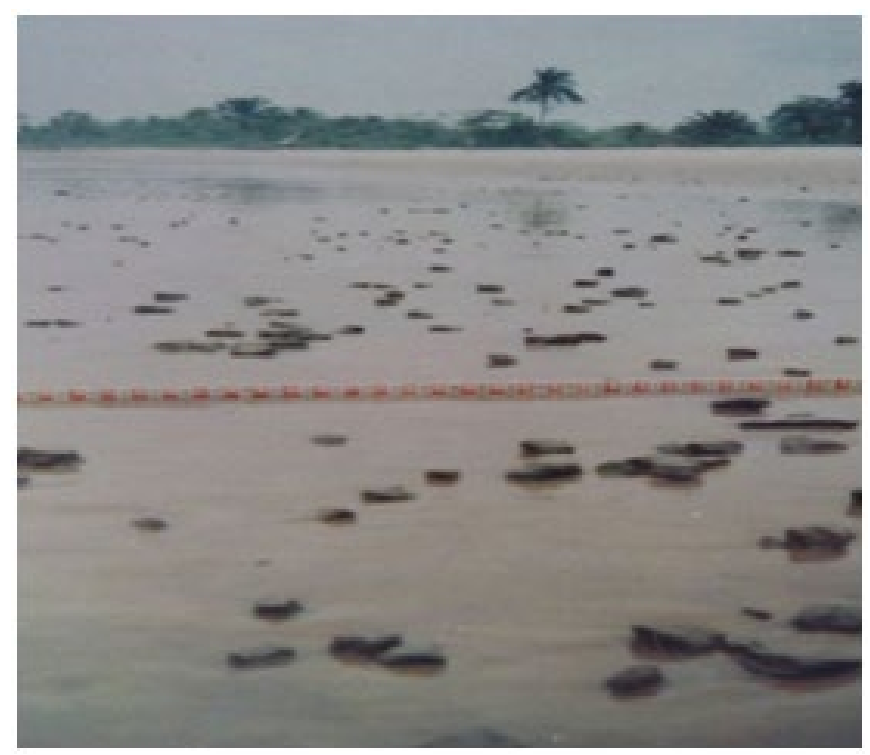

Figure 2. Alongshore view of the mid-foreshore

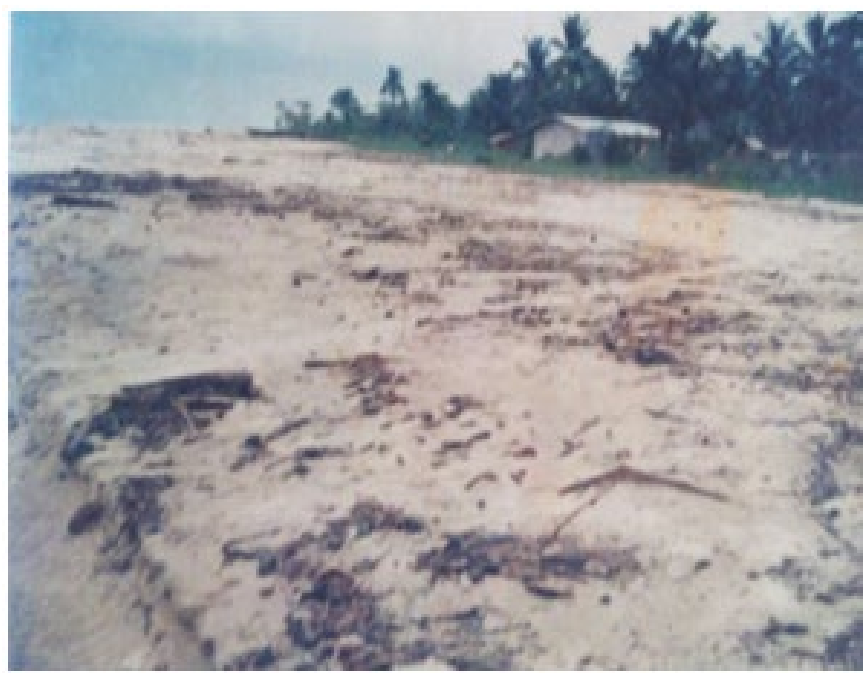

Figure 3. Alongshore view of backshore - berm region showing erosional edge

\subsection{Climate and hydrodynamic condition}

According to Adefolalu [11], the climate of Nigeria coast is tropical equatorial with sunshine being high throughout the year and maximum between January and May while minimum occurs in July and September. Temperatures range, on average, between 26 and $27{ }^{\circ} \mathrm{C}$ during the dry months of February to 
March and about $24{ }^{\circ} \mathrm{C}$ during wet months of June and September.

Daily temperatures oscillate between $31.7^{\circ} \mathrm{C}$ and $23{ }^{\circ} \mathrm{C}$ in dry season highest average values of humidity reach 90 in August as against an average minimum of $74 \%$ in February. Rainfall is most intense $(>3500 \mathrm{~mm})$ between April and October, the values being 5 - 7 times higher than in November to March $(500 \mathrm{~mm})$.

Tides in the study area are semi diurnal, with a mean range of $1.8-2.4 \mathrm{~m}$ the average value of the tidal range places Itak Abasi at beach in mesotidal regime based on the classification Davies (1964) cf Antia [12]. Wind and wave conditions along the Nigerian coast can be distinguished into three by Antia [10] namely calm (November - January), transition (February - April) and storm (May - October). Prevailing onshore (mostly southwesterly) winds have a modal velocity of $6-9$ $\mathrm{m} / \mathrm{s}$ with a marked increase in frequency during the storm season.

\subsection{Geologic setting}

Itak Abasi beach is the active ridge of a series of Holocene abandoned beach ridges backing it. The inter ridge spaces are prominently dominated by mangroves forming brackish water swamps. The beach is composed primarily of moderately to very well sorted, fine to very fine quartz and feldspathic grains. Biogenic activities in the soft-bottom sediments in the form of bioturbation structures Richter [19] by the macrozoobenthic groups are quite conspicuous in the beach. They move both surficial and internal sediments up to a depth of $1 \mathrm{~m}$ by burrowing, crawling, grazing and tunneling in the sediments [20-21].

\section{METHOD OF STUDIES}

Field investigations were conducted during the period spanning 30th September and 20 October 1995. After reconnaissance, the $5 \mathrm{~km}$ long study location was divided into 5 sectors and stations (1-5) established at $1 \mathrm{~km}$ intervals with station closest to the estuary. Data collected include morphologic, hydrodynamic and sedimentary characteristics.

\subsection{Morphologic features}

Principal amongst the morphologic features was the geomorphology of the beach which was evaluated through continuous beach profiling at each of the five study stations. Profiling was done with the aid of graduated staff $s$ and tape using the horizon as reference. The profile data were used to prepare geomorphological map of the study area (Figure $4 \mathrm{a}$ and Figure 4b).

A typical cross section distinguishes the beach into the backshore, berm, upper, middle and lower foreshore morphozones with the latter extending into the surf zone. The upper foreshore is taken to extend $20 \mathrm{~m}$ seaward from the berm edge succeeded by the mid foreshore which is $20 \mathrm{~m}$ long. The lower limit of the mid foreshore to the low tide water line defines the lower foreshore.

Beach profiles were conducted daily at the study stations from which estimates of day to day net volumetric changes at the beach morphozones over two time intervals (10 September - October 20 1995) was calculated.

\subsection{Hydrodynamic features}

Hydrodynamic parameters influencing the characteristics of the beach were monitored. These include longshore current velocity and direction, wave height, swash excursion length, and wave and swash periods. The longshore current velocity was estimated by tracking the movement of a floating object over known distances and corresponding drift time; drift direction was ascertained with the aid of a compass. The wave height at breaking was estimated with the aid of a graduated staff held just above the water level close to the breaker line. Wave periods and swash periods were obtained with use of stop watch. This involved observing a series of successive waves and swashes over known time intervals.

\subsection{Beach stability index}

The variations in the surf-scaling parameter as an index of beach mobility and or stability were evaluated using Guza and Inman [22] equation. It is given as

$$
\epsilon=H(2 \pi)^{-2} T^{-1} \mathrm{~g}(\tan \beta)^{-2},
$$

where $H$ is wave height, $\beta$ is beach slope, and $T$ is wave period.

\section{RESULTS AND DISCUSSION}

Typical daily beach profile measurements are presented in Figures $4 \mathrm{a}$ and $4 \mathrm{~b}$ along with tidal elevation curve during the neap tide of the study period (Figure 5) while the sediment volumetric change on the studied beach over time (10 September - 20 October 1995) calculation from the beach profiles are presented in Figure 6 showing the backshore berm, upper foreshore and mid foreshore morphozones to be characterized by net accretion with the highest volume recorded in the mid foreshore of station $2\left(+8.20 \mathrm{~m}^{3} / \mathrm{m}\right)$ and upper foreshore of station $1\left(+7.92 \mathrm{~m}^{3} / \mathrm{m}\right)$. By contrast, the lower foreshore was dominated by erosional activities, with highest erosion $\left(-15 \mathrm{~m}^{3} / \mathrm{m}\right)$ occurring close to the estuary.

Runup on a beach is a common attribute of a shoreline environment as the waves are constantly breaking and expending their energies. This process to a high degree affects the sediments water content, beach saturation and ground water table evaluation causing variable permeability characteristic on the in-situ beach sediments [13].

Moreover, sediments characteristics, especially mean grain size and sorting (Table 1) are known to exert a marked influence on permeability of beach sediments [22-23] which affect beach saturation, infiltration and sediment deposition and or exfiltration and erosion.

Higher mean grain size at low groundwater elevation in the mid-foreshore, upper foreshore and backshore - berm beach sun-environments are responsible for the accretion while a low water table at the still water line characterizes the erosion in the morphozone. Time-averaged beach mobility and or stability index varies from 140-260, 40-60, 15-30, 10-36, and 4-120 in stations 1, 2, 3, 4, and 5 respectively. Very high values $(>>33)$ of the parameter such as at the stations 1, 2 and 5 of the study area (Figure 7) suggests highly dissipative beach condition or low mobility tendency [24]. Some segments of the beach (station 3) depicts temporary low surf-scaling parameter values, hence a high mobility tendency. 
An increase in wave height (Figure 8) is usually accompanied by a large swash runup and excursion length with bedload and deposition. This is because with increase with swash period and runup length beach saturation and water content increase, thus raising the ground water table elevation and causing exfiltration and erosion.

It was noted that low values of swash $(\mathrm{t})$ to wave periods $(\mathrm{T})$ was typically found close to high water when plunging breakers increase in frequency; the opposite is the case at low tides when splitting breakers dominate the surf zone with decrease in $\mathrm{t} / \mathrm{T}$ ratio, increase infiltration is implied.

Table 1. Beach morphodynamic parameters

\begin{tabular}{|c|c|c|c|}
\hline \multicolumn{2}{|l|}{ Gradient } & & $2^{\circ}$ \\
\hline \multicolumn{4}{|c|}{ MEAN GRAIN SIZE (phi) } \\
\hline Backshore - Berm & \multicolumn{2}{|c|}{$2.03-2.27$} & Fine sand \\
\hline Upper foreshore & \multicolumn{2}{|c|}{$2.32-2.93$} & Fine sand \\
\hline Mid-foreshore & \multicolumn{2}{|c|}{$2.32-3.33$} & $\begin{array}{c}\text { Fine sand to } \\
\text { very fine sand }\end{array}$ \\
\hline Lower foreshore & \multicolumn{2}{|c|}{$2.17-2.88$} & Fine sand \\
\hline \multicolumn{4}{|c|}{ SORTING (phi) } \\
\hline Backshore - Berm & \multicolumn{2}{|c|}{$0.28-0.40$} & $\begin{array}{l}\text { Very well sorted - } \\
\text { moderately sorted }\end{array}$ \\
\hline Upper foreshore & \multicolumn{2}{|c|}{$0.29-0.80$} & $\begin{array}{l}\text { Very well sorted to } \\
\text { moderately sorted }\end{array}$ \\
\hline Mid-foreshore & \multicolumn{2}{|c|}{$0.55-0.76$} & $\begin{array}{c}\text { Moderately well sorted } \\
\text { to moderately sorted }\end{array}$ \\
\hline Lower foreshore & \multicolumn{2}{|c|}{$0.47-1.06$} & $\begin{array}{l}\text { Well sorted to } \\
\text { poorly sorted }\end{array}$ \\
\hline \multicolumn{2}{|l|}{ Profile } & \multicolumn{2}{|r|}{ Dissipative beach } \\
\hline \multicolumn{2}{|c|}{$\begin{array}{c}\text { Upper beach face } \\
\text { sedimentary structures }\end{array}$} & \multicolumn{2}{|c|}{$\begin{array}{c}\text { Swash marks, rill marks, } \\
\text { rhomboidal marks, } \\
\text { wave ripples, cuspate ripples }\end{array}$} \\
\hline \multicolumn{2}{|c|}{$\begin{array}{c}\text { Lower beach face } \\
\text { sedimentary structures }\end{array}$} & \multicolumn{2}{|r|}{ No structures } \\
\hline \multicolumn{2}{|c|}{$\begin{array}{c}\text { Internal sedimentary } \\
\text { structures }\end{array}$} & \multicolumn{2}{|r|}{$\begin{array}{c}\text { Parallel and } \\
\text { even lamination }\end{array}$} \\
\hline \multicolumn{4}{|c|}{ Dominant sediment mobilization } \\
\hline \multicolumn{2}{|c|}{ Backshore - Berm } & \multicolumn{2}{|r|}{ Net accretion } \\
\hline \multicolumn{2}{|c|}{ Upper foreshore } & \multicolumn{2}{|r|}{ Net accretion } \\
\hline \multicolumn{2}{|l|}{ Mid-foreshore } & \multicolumn{2}{|r|}{ Net accretion } \\
\hline \multicolumn{2}{|c|}{ Lower foreshore } & \multicolumn{2}{|r|}{$\begin{array}{l}\text { Dominantly } \\
\text { erosion }\end{array}$} \\
\hline
\end{tabular}

Sediments properties range from fine to very fine sands and are moderately to very well sorted and positively to negatively skewed. Kurtosis also varies from mesokurtic to leptokurtic.

Morphodynamic parameters (Table 1) depict typically fine to very fine sand. The Backshore - berm and upper foreshore regions are characterized by very well sorted - moderately sorted fine sand, while the mid foreshore is dominantly moderately well sorted to moderately sorted fine to very sand classes. The lower foreshore sediments were characteristically well sorted to poorly sorted fine sands (Table 1).

Daily averages of wave height during the study period (Figure 8) ranged between $20 \mathrm{~cm}-55 \mathrm{~cm}$; wave period between $3-18 \mathrm{sec}, 6-12 \mathrm{sec}$ the modal range while breaker pattern is dominantly spilling and plunging.

Longshore current (Figure 9) observed mostly close the low tide at the monitoring stations were dominantly eastward attaining a maximum velocity of $80 \mathrm{~cm} / \mathrm{s}$ close to the Qua Iboe river estuary. The highest frequency of westward directed longshore current was close to the estuary.

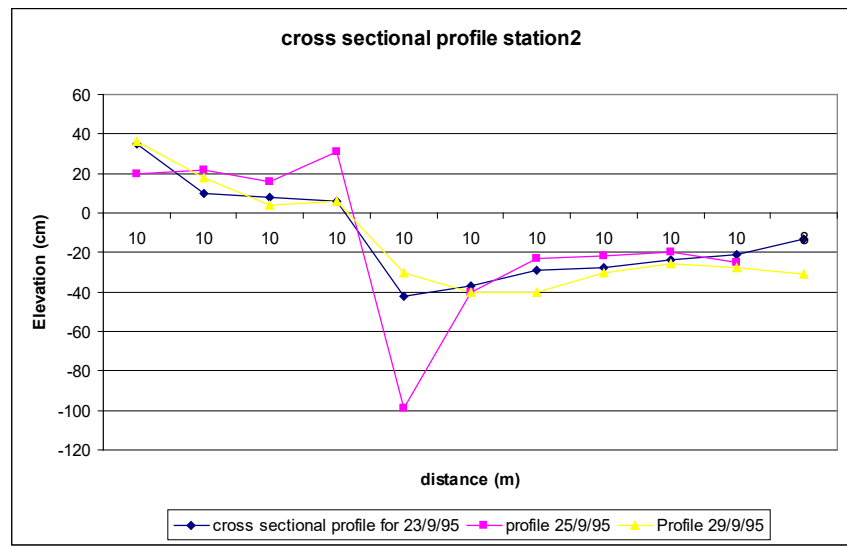

(a) Cross sectional profile of Station 2

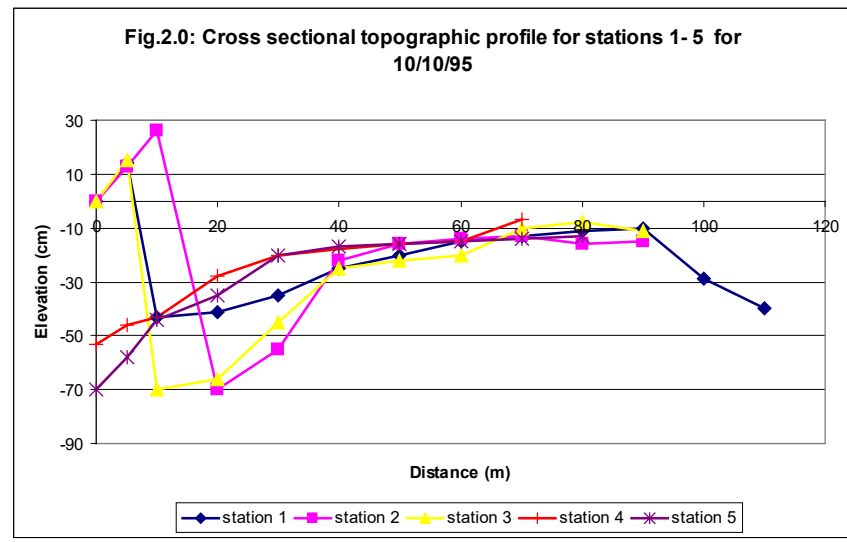

(b) Cross sectional profile of stations on 10/10/1995

Figure 4. Cross sectional topographic profile

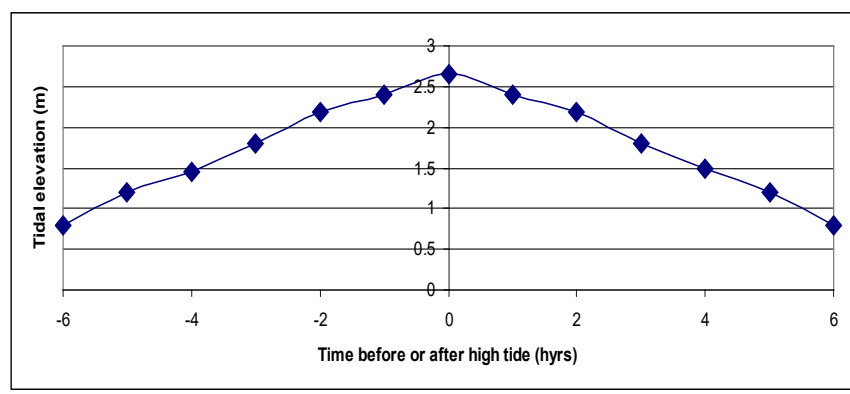

Figure 5. Typical tidal elevation curve during the study period

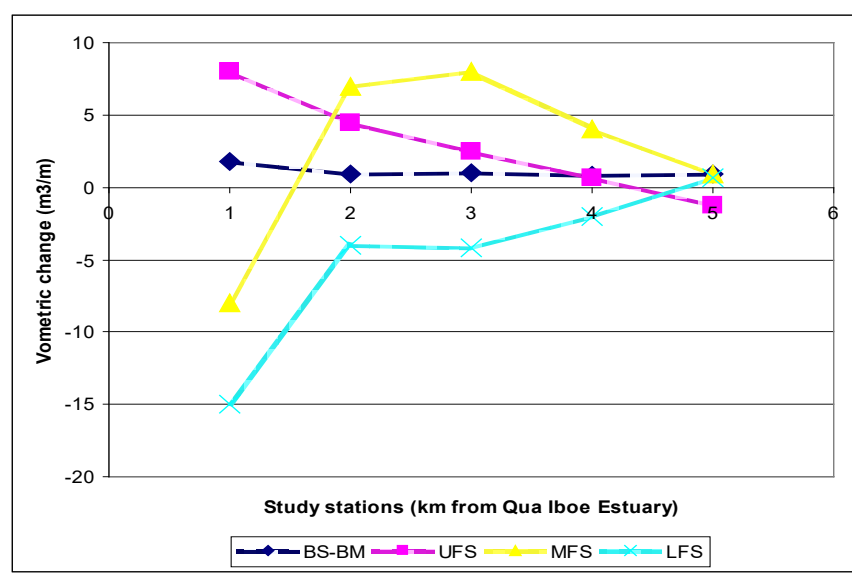

Figure 6. Sediment volumetric change 


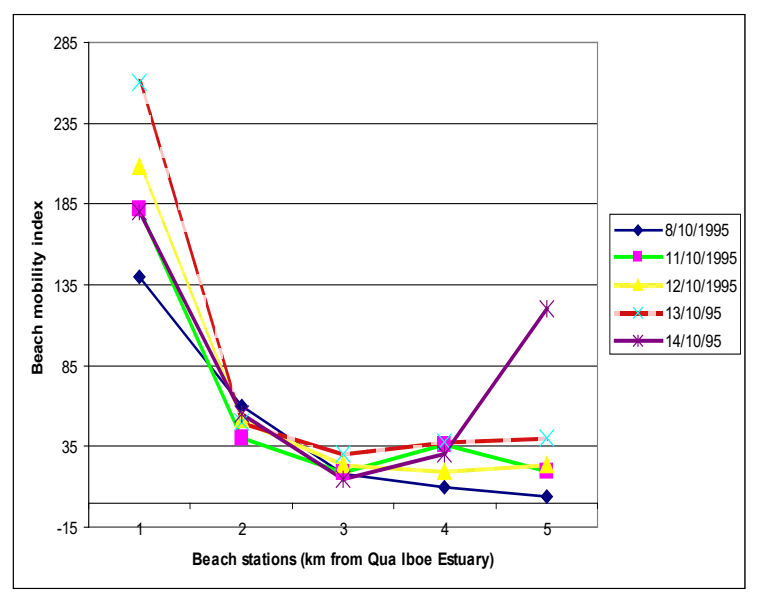

Figure 7. Beach mobility Index

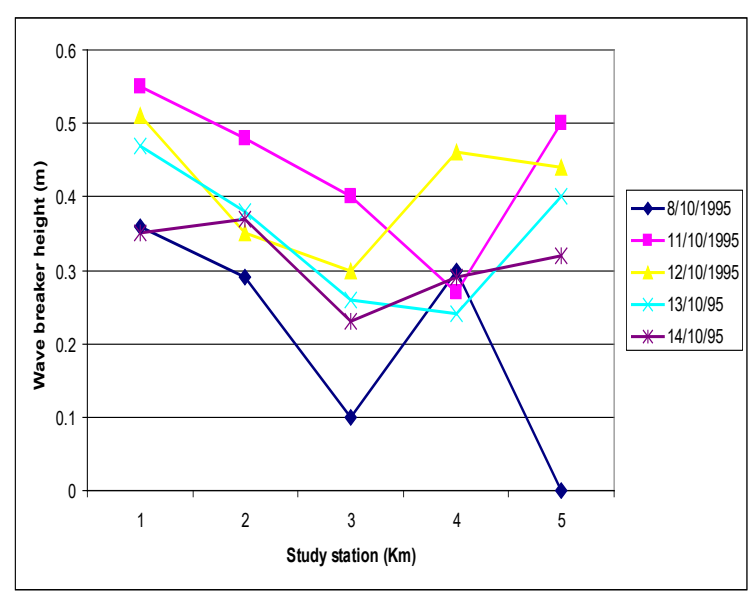

Figure 8. Wave breaker height

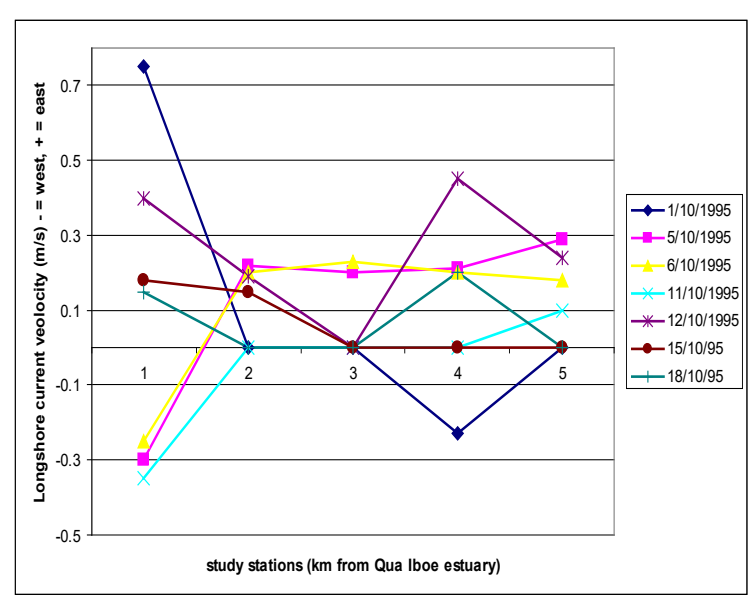

Figure 9. Longshore current velocity

\section{CONCLUSIONS}

The backshore - berm, upper foreshore and mid-foreshore sub-environment were characterized by deposition while the lower foreshore was dominated by erosion. Characteristic sedimentary processes were mainly winds, wave and tides. Sediment properties range from fine to very fine sands and are moderately sorted to very well sorted and positively to negatively skewed. Surf zone hydrodynamic were observed to exert a huge influence in the processes causing modification of the beach and erosion and accretion at different beach morphozones. It is recommended that the beach be developed as a tourist centre in view of its scenic beauty and periodic studies of the accretion and or erosion be carried out as predesign tool for shore protection works and as a basis for predicting the groundwater table elevation and migration saltwater into the oceanic coastal aquifers.

\section{REFERENCES}

[1] Komar, P.D. (1976). Beach Processes and Sedimentation. Prentice-Hall, Englewood Cliffs, New Jersey, pp. 429.

[2] Greenwood, B., Hale, P.B. (1980). Depth of activation, sediments flux and morphological change in a barred nearshore environment. In: McCann, S.B. (ed). The Coastline of Canada. Geological Survey, Canada paper 80-10, pp 89-109.

[3] Grant, U.S. (1946). Effects of groundwater table on beach erosion. Geological Society American Bulletin, 57.

[4] Grant, U.S. (1948). Influence of the water table on beach aggradation and degradation. Journal of Marine Research 7: 655-660.

[5] Carter, R.W.G., Orford, J.D., (1993). The morphodynamics of coarse clastic beaches and barriers: A short- and long-term perspective. Journal of Coastal Research, 15(Special Issue): 158-179.

[6] United States Geological Survey. (1998). SWASH: a new method for monitoring coastal erosion. USGS Information Handout.

[7] Sunamura, T., Horikawa, K. (1974). Two-dimensional beach transformation due to waves. Proc. 14th Coastal Engineering Conference ASCE, pp. 920-938.

[8] Antia, E.E., Nyong, E.E. (1988). Beach morphodynamics along the Nigerian coastline. Implication for coastal engineering project. Journal African Earth Science, 7: 553-559. https://doi.org/10.1016/0899-5362(88)90045-0

[9] Antia, E.E. (1987). Preliminary field of reservations of beach cusps formation and characteristics on tidally and morphodynmaically distinct beaches on the Nigeria coast. Marine Geology, 78: 23-33. https://doi.org/10.1016/0025-3227(87)90066-1

[10] Antia, E.E. (1989). A short term study of the effect of changing coastal condition on some geomorphological elements on Nigerian beaches. Zeitschrift F. Geomorpphologie, 73: 1- 16.

[11] Antia, E.E. (1993). A morphodynamic model of sand beach susceptibility to tar pollution and self-cleansing on the Nigerian coast. J. of Coastal Res., 9: 165-174.

[12] Antia, E.E. (1995). Tidal range-related reversal in grain size pattern on a tropical sandy beach of Nigeria. Senckenbergiana Maritina, 25: 142-153.

[13] Heathershaw, A.D., Carr, A.P., Blackely, M.W.L., Wooldrdga, C.F. (1981). Tidal variation in compaction beach sediments. Marine Geology, 41: 233. https://doi.org/10.1016/0025-3227(81)90082-7

[14] Engstrun, W.N, (1974). Beach foreshore sedimentology and morphology in the Apostle Island of Northern Wisconsin. J. of Sedimentary Geology, 1: 190-206.

[15] Chaudri, R.S., Khan, H.N.N., Kaur, S. (1981). Sedimentology of beach sediments of West Coast of India. Sedimentary Geology, 30: 79-94. https://doi.org/10.1016/0037-0738(81)90014-2

[16] Wadell, E. (1976) Swash groundwater - beach profile 
interactions. In: Davies, R.A., Elingthon, R.L. (eds). Beach Nearshore sedimentation. Soc. Of Economic Paleontologists and Mineralogists Special Pub. 24, Tulsa.

[17] Carling, P.A. (1982). Temporal and spatial variation in intertidal sedimentation rates. Sedimentology, 29: 17-23. https://doi.org/10.1111/j.1365-3091.1982.tb01705.x

[18] Adefolalu, D.O. (1981). The weather and climate of Calabar: a study of coastal microclimatology in equatorial tropics. Senate Research Project Report, University of Calabar.

[19] Richter, R. (1952). Fluidal-Textur in Sediment Gesteinen and über Sedifluktion überaupt. Notizblatt des Hessischen Landesamtes für Bodenforschung $\mathrm{zu}$ Wiesbaden, 3(6): 67-81.

[20] Frey, R.W. (1975). The realm of ichnology, its strengths and limitations. In: The Study of Trace fossils, (Ed. R.W. Frey) Springer -Verlag, New York, pp. 13-38.

[21] Bhattacharya, A., Sarkar, S.K., Bhattacharya, A. (2003). An assessment of coastal modification in the low - lying tropical coast of Northeast India and role of natural and artificial forcings. International Conference on Estuaries and Coasts November 9-11, 2003, Hangzhou, China.

[22] Guza, R.T., Inman, D.L. (1975). Edge waves and beach cusps. J. Geophys. Res., 80: 2997-3012.

[23] Chakrrabarti, P. (1990). Process-response system analysis in macrotidal and mesotidal coastal plain of Eastern India. Memor Geol. Surv. India, 2: 165-187.

[24] Wright, L.D., Short, A.D. (1984). Morphodynamics variability of surf zones and beaches: A synthesis. Marine Geology, 32: 93-118. 